\title{
Teaching EFL for Young Learners in Islamic Elementary Boarding School
}

\author{
Yoyok Agus Wahyudi* \\ English Language Education of Graduate School \\ Universitas Negeri Yogyakarta \\ Yogyakarta, Indonesia \\ yoyokagus.2018@student.uny.ac.id
}

\author{
Suwarsih Madya \\ English Language Education of Graduate School \\ Universitas Negeri Yogyakarta \\ Yogyakarta, Indonesia \\ suwarsihmadya@uny.ac.id
}

\begin{abstract}
- this research aims to describe how is teachingEnglish to young learners in the Islamic Elementary Boarding School in Yogyakarta. In this research, the writer uses descriptive qualitative research. The method used in this research is the descriptive method. The instruments used are an interview with the headmaster, English teachers and students, classroom and teaching-learning observation recorded by video, and observation checklists. This research was done three times a meeting to collect the data needed. The population of this research is all English teachers and all the students in the one of Islamic Elementary School in Yogyakarta, while the sample is two English teachers and all students in the fourth grade. Based on the interview and observation checklist from the field, there are three significant policies in teaching English as a foreign language in Islamic Elementary Boarding school. The first is that full-day English speaking class. It means that all the students and all the teachers use English $100 \%$ in their teaching-learning. The second is the school uses a reading log to boost the student's performance by applying their English skills. The third is the teachers use games, ice-breaking, challenge, and songs in teaching English. It is in line with the theories that introducing English in the Elementary is better than the older children. Interesting materials can improve motivation. When motivation is improved, everything develops. The interesting materials can be found in games, ice-breaking, and songs.
\end{abstract}

Keywords- English as Foreign Language, Young learners, Elementary School

\section{INTRODUCTION}

Young learners are those who are in the age of between five and twelve (Cameron, 2005). From this statement, the young learners are the children who are in pre-school and finish in primary school. Children have a different character than an adult in learning language so that the way of teaching should be different among those (Brewster \& Ellis, 2002). In learning language, adults have a long-term target, such as getting a job or studying in another country. Young learners are, on the other hand. They still cannot control their lives. They even learn both their language and another. The examples of characteristic of young learners are as follow: they have a lot of physical energy, and they need to be active. They usually get bored quickly. They learn something slowly and forget them easily.

Teaching English to children is the same as introducing English to young learners as a foreign language, while children do not understand why it is important to study a foreign language. Developing a joy and attractive teaching- learning activity or environment is able to prepare learners for their successful life and give more opportunities in the advanced courses later in their school careers. One of the most essential aspects of teaching English to young learners is to develop joy and attractive learning activities. For some children, studying English is the same as just the usual activity in their daily life in spite of taking time for them in understanding the future impact of what they are studying, the basic skills that these children study will prepare them for a more future language lesson. Teaching English to young learners should be attractive to parents, teachers, and administrators and workable to children (Brewster \& Ellis, 2002 , p. 3). Fun activities such as to incorporate new words into songs and games can help young learners relax and enjoy the learning activity. The kids are easily bored so that the variety of teaching should be applied to keep the young learners engaged and motivated. Focusing activities on alphabet, numbers, and colors allow much creativity in the lesson plan.

Young learners have different emotional needs; they own the emotional excitement, they are not only easily distracted but also very enthusiastic, and they are able to concentrate for a surprisingly long time if they are in the exciting mode (Brewster \& Ellis, 2002). From his statement, we can assume that young teaching learners are different from an adult so that the teachers have to consider their syllabus, lesson plan, and method in teaching young learners. According to Madya, in her lecturing of young learner class, she mentions that teaching English to young learners should consider several techniques. The first is that repeating. Repeating is very important in teaching English to young learners. The kids quickly forget so that repeating can save the material quickly to their minds. The second is that challenging.

The kids are engaged to be tested. Materials that challenge young learners will much better than explanatory. The third is involving. Children are interested in being involved. They will be excited to finish all the materials when they are involved. If they are not included, they will seek another activity to make them busy by themselves, such as disturbing their friends or making noise in the class. The fourth, children like moving. The large space classroom will be better. They will be free moving and will not feel to be restricted. The fifth is that the class should be fun decorated in English words, colored pictures, and fresh air. It will stimulate the students 'learning, feeling joyful, and attracting them. "using games as a tool in teaching vocabulary to young learners" (Bakhsh, 2016), he states that 
one of the effective ways to teach young learners is using games. It makes the students easier to remember the meaning. Besides, teaching young learners should be attractive and fun for teachers, parents, and students (Linse, 2005).

According to Indonesian educational law number 24 in 2009 , the government accommodates the foreign language to be taught in school to face the globalization. Because modernism and technology have developed rapidly, the Indonesian government also prepares the international language at an early age. The government accommodates the law related to the teaching of English as a foreign language, but implementing English as a lesson in primary school depends on the schools themselves. Some schools include English as a lesson in their curriculum while others do not. The reason which the government cannot obligate all primary schools to include English in their curriculum is that Indonesia is a multicultural language country. Many local languages are spoken in different areas, and the government also accommodates the local language to be taught in school as a national heritage. It means that the Indonesian government preserves the local language, which spread a lot in Indonesia and also accommodates the foreign language to be taught in school to prepare the globalization.

Teaching English to young learners should be attractive and fun (Puskas, 2016), but in Indonesia, some primary schools still use textbooks that use teacher-centered as the method. Sometimes the students are crowded by themselves because they feel that they do not involve in the activity. The classroom is not large, so the students can not feel free to move. From this explanation and some observation, the researcher finds the gap that the theories of teaching English to young learners cannot be implemented to all Indonesian primary schools. From this study, the researcher wants to know the description of teaching English to young learners in one of the Islamic primary schools in Yogyakarta, and from this study, the researcher will get the data and fact what theories have been implemented in that school-related teaching English to young learners.

This research is different from previous research because this research describes how teaching English to young learners is described in general. The writer describes the real condition of how the teaching-learning process is done while previous researchers describe a particular model of teaching and techniques in teaching English to young learners (Aziza \& Syafei, 2018; Bakhsh, 2016; Kalantari \& Hashemian, 2016; Wardiah \& Syafei, 2016; Yolageldili \& Arikan, 2011). They all describe particular techniques in teaching English to young learners such as using game, video or storytelling.

Some reasons why the writer selects the Islamic boarding school chosen as research place are: the first is that Islamic elementary boarding school is multicultural students and Multilanguage. The students learning in this school come from a lot of different places not only from Indonesia but also from another country. They have a variety different background family from different ethnics. They use English and Arabic as communication, but they also speak their mother tongue and national language that is Indonesian. This is a unique situation where the students who come from different parts of the place and country study together and interact with each other using a foreign language at an early age. They speak their native languages, the national language, English and Arabic. The second is that Islamic elementary boarding school is an international school which uses full-day English in teaching-learning. The writer wonders how the seven-year students are able to communicate English in the learning process and communicate with others by using English.

\section{LITERATURE REVIEW}

\section{A. Foreign Language Learning at Elementary Level}

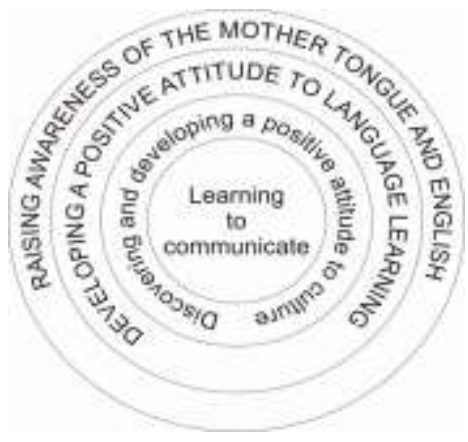

Fig. 1. The Objectives of Early Learning of English

The objectives of the early learning of English as the figure above (Brewster \& Ellis, 2002). In learning to communicate the foreign language, the students have to discover and develop a positive attitude to culture, develop a positive attitude to language learning, and raise awareness of the mother tongue and English. The general purpose of learning a foreign language at an early age is attractive not only to students but also to parents as well as to administrators (Brewster \& Ellis, 2002). The aim of foreign language learning is not to prepare bilingual students, but it prepares children linguistically, psychologically, and culturally for language learning. As Psychological preparation, the teachers have to create ways for how students interesting in learning English. For example, in Japan, Primary English language Teaching aims to motivate the learner and to learn English for fun. The Minister of Education states it. In Indonesia, the aims of teaching English is to motivate children by using interesting and fun ways. In Spain, ELT aims to recognize and appraise the communicative value of foreign language and their capacity to learn how to use it. As linguistic preparation, the main language purpose for primary in teaching English is to develop communicative competence. As Cultural preparation, many countries in the world states that the objective of foreign language teaching and learning is to develop intercultural awareness. However, children are different from an adult in learning (Cameron, 2005, p. 17). For example, children are likely to make the teacher happy than their peer. They easily get bored with the lesson even though they enthusiastic. Knowing the characteristic of children is to determine the success of teaching-learning. 


\section{B. Young Learners}

Young learners categorize into three groups (Pinter, 2006). The first is children who begin pre-school at the age of three years old. The second is children who begin the primary level between the ages of five to seven years old. The third is children who finish their primary school at the age of eleven or twelve while Lynne Cameron agrees that young learners are children in the age between five and twelve. Young learners are called pupils who are in the age from five to eleven years old (Scott \& Ytreberg, n.d.). From the three experts, the conclusion can be made that young learners are children between five to eleven years old.

\section{Islamic Elementary Boarding School}

Islamic boarding school accommodates the students to study formally at school and also facilitates the students who stay in the boarding house with religious activities. This school does not obligate the students to stay in the boarding house. Some students go home after formal education finishes. This accommodate nationalism, Islamic and globalization to prepare the students. It is unique because this school introduces Islamic value, accommodates the foreign language (English and Arabic) in the school, and also introduces and preserves local and national language. One student has to learn English, Arabic, Javanese, and Indonesian language. Furthermore, most learners take benefit and positive impact of living in cross-cultural living (Brown, 2007). They get positive effects incorporating cultural awareness in the language classroom.

This is the reason of the writer chooses the Islamic elementary boarding school to do the research. The students live together with their classmates who are from different region, tribes, languages, and countries. They are Multilanguage and cultures but they communicate with English and Arabic.

\section{RESEARCH METHOD}

There will be three parts to this chapter. They are participants, instruments, and data analysis procedures.

\section{A. Research Problem}

This research was conducted in an attempt to address the research questions. The research questions ware as follow:

a. How was the description of teaching English for young learners in Islamic elementary boarding school?

b. What techniques were used in teaching English for young learners in Islamic elementary boarding school?

\section{B. Research Design}

In line with the research design above, this research applied a descriptive qualitative method in order to describe as detail as possible how the description of teaching English for young learners in Islamic elementary school and what techniques were used in teaching English to young learners.

\section{Research Site}

This research was conducted in one of the Islamic elementary school in Yogyakarta. The researcher selected this school because this school had a different characteristic of combining other schools. Islamic elementary boarding school is multicultural students and Multilanguage. A culture introduces for every person a context of effective cognitive behavior (Brown, 2007, p. 202). The students learning in this school come from a lot of different places not only from Indonesia but also from another country. They have a variety different background family from different ethnics. They use English and Arabic as communication, but they also speak their mother tongue and national language that is Indonesian. This is a unique situation where the students who come from different parts of the place and country study together and interact with each other using a foreign language at an early age. They speak their native languages, the national language, English and Arabic. The second is that Islamic elementary boarding schools use full-day English in teaching-learning. the seven-year students are able to communicate English in the learning process and communicate with others by using English

\section{Participants}

The participants of this research were two English teachers, one principal, and all students of third grades in one of the Islamic elementary schools in Yogyakarta. The writer interviewed the principle, two English teachers, and some students.

\section{E. Data Collection and Instruments}

The researcher collected the data using guided interviews, observation checklists, and observation. The interview was intended for the principle, all English teachers, and some students. The interview was done to know the real condition of how the description of teaching English to children in one of the Islamic elementary school in Yogyakarta. The observation checklist can be a very simple and better option for focusing on only a few factors within real-time (Brown, 2007, p. 269). The observation checklist and observation were done to know the real condition of teaching English in the researcher's perspective, such as the method of teaching, materials, the student's interactions, and classroom decorations and management. The interview was recorded on a mobile phone. The observation checklist was done using printed paper containing instruments. The observation was done by taking the pictures.

\section{F. Data Analysis}

The data were analyzed by using descriptive qualitative. Qualitative research is useful for understanding a range of societal issues that arise from a particular cultural context (Tracy, 2013, p. 27). The observation checklists were analyzed. It was combined with the expert statements about the suitable condition in teaching English for young learners with real conditions. The observation was taken by video to see the real condition in teaching-learning. The guided interview was taken to see the principle, English teachers, and student's statements related the teaching-learning. From those aspects, the real phenomenon in teaching English can be described well. The writer described the phenomenon according to the results of the interview and observation checklist and observation. 


\section{FINDINGS}

After the researcher .did the observation, observation checklists, and interview, the findings are figured out as follow:

\section{A. Full day English}

Full day English was used in every day teaching English. According to the result of the interview recorded from the principle and English teachers, the classroom activities were instructed using English 100\%. It was in line with the result of the observation. The observation showed that all the students and the teachers communicated in English 100\%. The students were very active in using their English. Below was the result of the interview between the researcher and one of the English teachers.

The researcher: good afternoon sir,

Teacher 1: good afternoon

The researcher: I wonder how the students can speak English in the class. How do you prepare your students?

The teacher 1: well, we encourage them to speak English in all activities in the class. It means we have them speak in everyday class.

The researcher: Does the school make them speak?

The English teacher 1: Yes, but we guide and encourage them. For the students who have low English, we advise them, help them personally after the class done. But speaking English in the class is obligatory.

The researcher: Do the students have the same background in English?

Teacher 1: No, they have different backgrounds. Some are good in English while others not.

The Researcher: Does the school select the students who only good in English to enroll in this school so that the teaching-learning will be easier?

The English teacher 1: No, Anyone can enroll without discrimination, whether they are good in English or not.

The researcher: What is the obstacle in implementing full-day English or obligatory English because the ability of the students is different from the others?

\section{B. Reading $\log$ and writing Journal}

According to the interview with the principle, the featured programs in this school are reading log and writing journals. Here the result of the interview with the principle.

The researcher: good morning, Mom?

\section{The principal: Good Morning,}

The researcher: How is the teaching-learning of English here implemented?

The principle: we have excellent programs. They are reading $\log$ and writing journals. The reading $\log$ is a collection of many books in the library that the students can bring to their homes and replace them with another book. It has ten levels. It starts with the beginner to advance.
The researcher: how do the students choose a suitable book for them?

The principal: At first, we tested the students' ability in reading then we choose their levels according to their ability.

The researcher: What do the books contain for the beginners and for the advanced?

The principal: For level one, they contain simple sentences. For example, "I can run, I can cook, I can read, etc. for level ten, they contain stories like Narnia, Harry Potter. They like Novels.

The researcher: What grade of students are at level ten?

The principle: In the fourth grade above, some students in class four have been at the highest level.

The researcher: what is writing a journal?

The principal: writing journals is the process of writing the feeling, activity, moments, etc. which are done by the students every day. The students can share their experiences, ideas, or feeling in this journal.

The researcher: "You said this school implements fullday English or Obligatory English. What is the obstacle to implementing full-day English?

The principal: For the first three months are the hardest for the students to adapt to this system. Some students are good at English, but others are not. They can pass it after three months, June, July, and August, while October they have SLC (Student Lead Conference). Presenting their experience to their parents as long as 45 minutes in English

\section{Games, Challenge, and Icebreaking}

According to the observation and interview, the English learning in one of the Islamic primary Schools in Yogyakarta used games, challenges, and ice breaking. Games could encourage the students to speak English, made the students active, and promote repetition. Here was the interview was done with the English teacher after teaching.

The researcher: Good afternoon Sir,

The English teacher 2: Good Afternoon

The researcher: What method did you use in teaching English?

English Teacher 2: Mostly, I used games, challenges, and ice breaking.

The researcher: Why games?

English Teacher 2: Games are a natural part of childhood, and it can increase motivation. It is interesting, fun, attractive.

The researcher: How do you prepare your materials?

English teacher 2: I always make different in an everyday classroom, but the most important that we should be ready with the new method. Don't bring the same technique; it will be boring for the students. Be creative and make your class different. Don't make them boring.

The researcher: what is the benefit of challenge and icebreaking?

The English teacher 2: challenge accommodates the active students to show their ability, increase motivation, and encourage activeness. Ice-breaking is used to release the boredom. 
The researcher: what kind of games do you use to teach English to young learners?

The teacher 2: I usually use Board games, Card games, roleplay games, singing and chant games, guessing games and team games

\section{Observation checklist}

Here was the observation checklist which the writer noted during the teaching-learning in the one of Islamic elementary boarding school in Yogyakarta.

TABLE 1. THE OBSERVATION CHECKLIST

\begin{tabular}{|c|c|c|c|}
\hline No & Statements & Yes & No \\
\hline 1. & $\begin{array}{l}\text { The teacher uses English in the class } \\
\text { more than } 75 \% \text { of all the activities }\end{array}$ & $\sqrt{ }$ & \\
\hline 2. & $\begin{array}{l}\text { The students often use their English in } \\
\text { classroom activity than another } \\
\text { language. }\end{array}$ & $\sqrt{ }$ & \\
\hline 3. & $\begin{array}{l}\text { The students often use another language } \\
\text { in the for communication in the } \\
\text { classroom }\end{array}$ & & $\mathrm{V}$ \\
\hline 4. & $\begin{array}{l}\text { The teacher links the previous lesson } \\
\text { with the new lesson or topic }\end{array}$ & $\sqrt{ }$ & \\
\hline 5. & $\begin{array}{l}\text { The teacher repeats the materials and } \\
\text { gives an example until the students } \\
\text { understand the whole topics discussed. }\end{array}$ & $\sqrt{ }$ & \\
\hline 6. & $\begin{array}{l}\text { The teacher is patient to the low } \\
\text { students. }\end{array}$ & $\sqrt{ }$ & \\
\hline 7. & $\begin{array}{l}\text { The teacher gives a challenge to fast } \\
\text { learners. }\end{array}$ & $\bar{V}$ & \\
\hline 8. & $\begin{array}{l}\text { The teacher links the materials and the } \\
\text { student's experiences. }\end{array}$ & $\mathrm{V}$ & \\
\hline 9. & $\begin{array}{l}\text { The teacher gives a concrete example to } \\
\text { the students. ( the example is real ) }\end{array}$ & $\sqrt{ }$ & \\
\hline 10. & $\begin{array}{l}\text { The teacher teaches some new words to } \\
\text { the students in every meeting. }\end{array}$ & $\sqrt{ }$ & \\
\hline 11. & $\begin{array}{l}\text { When there is a problem arising in the } \\
\text { classroom, the teacher can manage and } \\
\text { solve it well. }\end{array}$ & $\sqrt{ }$ & \\
\hline 12. & $\begin{array}{l}\text { The teacher always starts } \\
\text { communication with the students in the } \\
\text { classroom. }\end{array}$ & $\sqrt{ }$ & \\
\hline 13. & $\begin{array}{l}\text { The students have the opportunity to } \\
\text { begin the conversation with the teacher. }\end{array}$ & $\sqrt{ }$ & \\
\hline 14. & $\begin{array}{l}\text { The teacher give questions to the } \\
\text { students. }\end{array}$ & $\sqrt{ }$ & \\
\hline 15. & $\begin{array}{l}\text { The students have the opportunity to ask } \\
\text { some questions to the teacher. }\end{array}$ & $\mathrm{V}$ & \\
\hline 16. & $\begin{array}{l}\text { The teacher creates fun and interesting } \\
\text { activity. }\end{array}$ & $\sqrt{ }$ & \\
\hline 17. & $\begin{array}{l}\text { The teacher use media, which stimulates } \\
\text { students' five senses. }\end{array}$ & $\sqrt{ }$ & \\
\hline 18. & $\begin{array}{l}\text { The teacher uses all medias available in } \\
\text { the classroom maximally. }\end{array}$ & $\mathrm{V}$ & \\
\hline 19. & $\begin{array}{l}\text { The students use daily English } \\
\text { expression in the classroom. }\end{array}$ & $\sqrt{ }$ & \\
\hline 20. & $\begin{array}{l}\text { The teacher uses gestures in teaching- } \\
\text { learning in the classroom. }\end{array}$ & $\mathrm{V}$ & \\
\hline 21. & The teacher links one activity to & $\sqrt{ }$ & \\
\hline
\end{tabular}

\begin{tabular}{|c|c|c|c|}
\hline & another. & & \\
\hline 22. & $\begin{array}{l}\text { The students respond to the learning } \\
\text { activity enthusiastically. }\end{array}$ & $\sqrt{ }$ & \\
\hline 23. & $\begin{array}{l}\text { The students use their mother tongue } \\
\text { language in the learning activity in the } \\
\text { classroom. }\end{array}$ & & $\mathrm{V}$ \\
\hline 24. & $\begin{array}{l}\text { The students collaborate with each other } \\
\text { in the classroom activity. }\end{array}$ & $\sqrt{ }$ & \\
\hline 25. & $\begin{array}{l}\text { The teacher gives a lot of examples in } \\
\text { every learning materials. }\end{array}$ & $\mathrm{V}$ & \\
\hline 26. & $\begin{array}{l}\text { The teachers group the students with } \\
\text { different ability. }\end{array}$ & $\mathrm{V}$ & \\
\hline 27. & $\begin{array}{l}\text { The teacher links the English lesson } \\
\text { with another subject. }\end{array}$ & $\sqrt{ }$ & \\
\hline 28. & The students use English confidently. & $\sqrt{ }$ & \\
\hline
\end{tabular}

\section{E. Observation pictures}

Wall decorated classroom
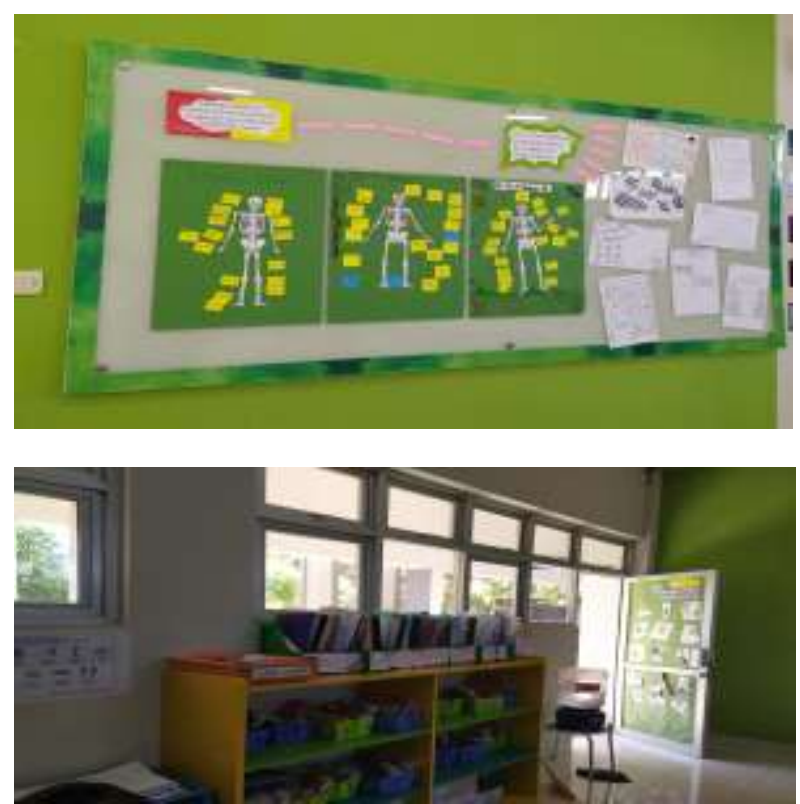

Student's challenge activity

\section{DISCUSSION}

Related to the research questions, the writer discusses two problems arising. The first is that how is the description of teaching English to young learners in the Islamic elementary boarding school. There were three main topics that were discussed in this section. The first was the full-day English. According to the findings, one of the Islamic primary schools in Yogyakarta applied full-day English $100 \%$ in their teaching-learning. According to the guided interview of the principle of Islamic elementary boarding school, the implementation of full-day English in teaching English to young learners had some obstacles in the three months earlier. It was in July, August, and September. These three months were crucial for the new students because they needed adaptation in all their learning. After 
three months of adaptation with the learning and environments, they were ready to present their English to their parents named SLC student leadership conference. The students had to present a fourth five-minute seminar in English. Full day English or Obligatory English was good because introducing English to young learners at an early age was better, and they liked to talk even though they did not know much about language (Brewster \& Ellis, 2002, p. 40). Regarded to observation checklist, the students were very active in learning because the teacher encourages their motivation. Good learning atmosphere could create successful learning. Students' centered learning combined good classroom management was developed in this class. It was believed that a comfortable classroom leads students to focus and concentration.

The following discussion was related to the reading log and writing journal. Reading log was the process of reading the books of the students, which began in the first semester of the first grade. In line with Brewster, he states that by the time the young learners learn to read successfully, they increase different forms of awareness and knowledge (Brewster \& Ellis, 2002, p. 110). The reading log consisted of the collection of books that had ten levels. The lowest level was level one. This level was used to the lowest students in reading. It consisted the simple sentences such as "I run, I walk, I study, I drink, etc. every day the students could replace the books and took another level, but they had to be tested before. The highest level was about completed stories such as Narnia and Harry Potter. It was like a novel. This was level ten. Usually, when the students had been in grade four, they read the tenth level. The activity of the reading log was perfect for young learners (Linse, 2005). Reading for information can be as simple as the reading menu in the restaurant if the students are used to doing it. If the young learner's mother used a cookbook, the children could help new recipes to their mother. Still related to how the teaching English to young learners in Islamic elementary boarding school, this school also had a writing journal to train the students to share their feeling and ideas. Every day the students had to write the journals. They had to share their feeling and ideas of what they were feeling on that day. Writing journals was perfect for young learners because it was in line with Ellis, he states that the concept of the writing process is very good for young learners because writing is good in memory aid (Brewster \& Ellis, 2002, p. 119). It was the same idea as Nunan. He states that the final piece of writing or product has grown up with many steps that make up the process (Linse, 2005).

The second discussion was related to the second research question about how was the techniques used in teaching English to young learners in one of Islamic elementary boarding school in Jogjakarta. According to the observation, interview, and observation checklist listed in the findings section, there were some techniques used in teaching English. The first technique was the game. The teacher used a game to teach English to young learners. The games were really good at teaching. The teacher modified the materials into games. It made the students were very active, joy, and fun. This finding is in line with Ellis. He states that children enjoy constructive play and games because they are both motivating and fun. It also provides best practice to improve pronunciation, vocabulary, grammar and other English skills
(Brewster \& Ellis, 2002, p. 172). The teacher also gives icebreaking when the students look bored. As long as two hours of learning English, the students did not realize that they were learning. They just enjoy the games. Related to the interview and observation, the teacher always used different games in everyday learning. Board games, Card games, role-play games, singing and chant games, guessing games and team games were the example. The teacher believed that fun activity made the students happy. Challenge promoted the students to be active. They tried hard to conquer their rivals or their own time. The active students would feel enthusiastic, so would the others. It is in line with Ellis and Brewster's statement that games are efficient in teaching young learners.

\section{CONCLUSION}

Teaching English to young learners has to be fun, interesting, attractive, and promote intercultural awareness. According to the discussion, teaching English to young learners in an Islamic elementary school was enjoyable. The school had full-day school English as regulation. The reading log was an excellent program. It was used to create students' habit of reading and introduce cultural awareness. Writing a journal could explore the students feeling, ideas, and experiences. Classroom management was very interesting. The room had adequate space to let the students move freely. The wall was fully decorated in pictures and English words. While all activities were instructed in English, the teachers paid attention more to the low students. There was consultation after class to them. For the technique in teaching students, the teachers use the game, challenge, and icebreaking and chants in teaching. Games, challenges, and icebreaking believed could create the attractiveness of students. Ice-breaking can reduce the boredom of the students. Challenge can motivate the students to be active and attractive From those models of teaching English as a foreign language, one of the Islamic elementary boarding school in Yogyakarta has introduced how teaching English which can promote the students psychologically, linguistically, and culturally. It can be a model for another school in teaching English to young learners who consider student's centered learning.

\section{REFERENCES}

Aziza, W., \& Syafei, A. F. R. (2018). Using cartoon film series " shawn the train " as media in teaching vocabulary to young learners. Journal of English Language Teaching, 7(1), 112-122. Retrieved from http://ejournal.unp.ac.id/index.php/jelt/article/view/9718/7222

Bakhsh, S. A. (2016). Using games as a tool in teaching vocabulary to young learners. English Language Teaching, 9(7), 120-128. https://doi.org/10.5539/elt.v9n7p120

Brewster, J., \& Ellis, G. (2002). The Primary English Teacher's Guide. Pearson Education Limited.

Brown, H. D. (2007). Principles of Language Learning and Teaching. Englewood cliffs, New Jersey: Prentice Hall.

Cameron, L. (2005). Teaching Languages to Young Learners (8th ed.). Cambridge , United Kingdom: Cambridge University Press.

Kalantari, F., \& Hashemian, M. (2016). A Story-Telling Approach to Teaching English to Young EFL Iranian Learners. English Language Teaching, 9(1), 221. https://doi.org/10.5539/elt.v9n1p221

Linse, C. T. (2005). Practical English Language Teaching: Young Learners (D. Nunan, ed.). New York: McGraw-Hill Companies, Inc.

Pinter, A. (2006). Teaching Young Language Learners. Oxford: Oxford University press.

Puskas, A. (2016). The Challenges and Practices of Teaching Young 


\section{Learners.}

Scott, W. A., \& Ytreberg, L. H. (n.d.). Teaching English to Children. London: Longman Education text.

Tracy, S. J. (2013). Qualitative Research Methods (1st ed.). West Sussex, UK: A John wiley \& sons.

Wardiah, I., \& Syafei, A. F. R. (2016). The use of funbrain game to improve young learners' english mastery. Journal of English
Language Teaching, 5(1), 390-396. Retrieved from http://ejournal.unp.ac.id/index.php/jelt/article/view/7342/5770

Yolageldili, G., \& Arikan, A. (2011). Effectiveness of using games in teaching grammar to young learners. 15th International Conference on Microwaves, Radar and Wireless Communications, MIKON 2004, 10(1), 219-229. 